\title{
Die Koninkryk van God - Grondplan van die Bybel 1
}

J A Heyns

\begin{abstract}
\end{abstract}
The Kingdom of God - Ground plan of the Bible

The Bible does not only look like a book, in reality it requires to be read and understood as a book. But then not as a book written by a variety of authors with a great number of divergent and even contradicting stories, but as a book with a unique unity, in spite of its diversity of authors and perspectives. Through the authors God opens His heart for mankind and discloses His deepest intention with His creation. This article defends the view that God's intention with His creation is expressed in the concept of the kingdom of God. Therefore the ground plan of the whole Bible and not only certain portions of $i t$, is also to be considered as that of the kingdom of God. This truth is grippingly illustrated in our Lord's thought and teaching. There the idea of the kingdom acted as a crystallizing point around which several other elements of truth naturally gathered and grouped themselves in harmonious combination.

\section{INLEIDING}

'n Afskeidsgeleentheid leen hom tot allerlei soorte misbruike. Twee van die voor die handliggende moontlikhede is die volgende: 'n nostalgiese terugvlug na die verste verlede, want daar is die beelde en die indrukke, belewenisse en gebeurtenisse dikwels duideliker en minder uitwisbaar as dié van die resente verlede. Die tweede moontlikheid is ' $n$ neurotiese wegvlug van die toekoms, want daar staan die afwesigheid van 'n vol en produktiewe lewe en die veeleisende uitdaging van nuwe aanpassings bedreigend voor jou. In albei hierdie gevalle staan die subjektiewe ervaring van die mens in die sentrum. Ek is nie van plan om in die rigting van een van hierdie twee moontlikhede te beweeg en my afskeidsrede 'n uitstalvenster van allerlei subjektiewe ervaringe en gevoelvolle emosies te maak nie ${ }^{2}$.

Die koninkryk van God - grondplan van die Bybel

Indrukke van jarelange omgang met teologiese studente - veral soos weerspieël word in mondelinge eksamensituasies - is dat hulle wel afsonderlike vakke slaag maar nie in staat is om die kennis wat hulle in daardie vakke verwerf het altyd tot 'n eenheid te integreer nie. So groei die oortuiging en die mening word gestimuleer dat die teologie saamgestel is uit 'n aantal geïsoleerde dissiplines soos byvoorbeeld 
Ou Testament, Nuwe Testament, Dogmatiek, Kerkgeskiedenis en Praktiese Teologie, waartussen die inhoudelike verbande en die saambindende sentrale tema nie duidelik is nie, en moontlik selfs geheel en al ontbreek.

Dié toedrag van sake mag egter nie net aan die gebrek aan ervaring by jong teologiese studente toegeskrywe word nie, en ook nie net aan bepaalde onmiskenbaar aanwesige tekortkominge in die metodologie van die aanbieding nie, maar vind sy oorsaak op 'n veel dieper vlak. Met groot vrymoedigheid en oortuiging kan gepraat word van 'n diep ingrypende krisis in die moderne wetenskapsbeskouing wat op sy beurt weer lei tot 'n ernstige verskeurdheid in die moderne kultuurbewussyn. Oorsaak van hierdie krisis is geleë in die onlesbare dors en onstuitbare drang na spesialisasie met fragmentasie as onvermydelike gevolg. Met die duiselingwekkende toename van insigte op grond van wetenskaplike en tegnologiese ontwikkeling, het die moderne mens grootliks die samehang van sy nuutverworwe insigte verloor. Op die ingrypende konsekwensies van hierdie ontwikkeling kan ons hier nie ingaan nie. Ons konstateer alleen net dat die teologie dié krisis nie vrygespring het nie. Ook hier het spesialisasie tot versplintering gelei.

Die teologie word tans in 'n verskeidenheid selfstandige vakgebiede ingedeel wat onmiskenbaar saamhang met die bestaan van 'n verskeidenheid aspekte binne die teologie self. Hierdie indeling dateer egter uit die einde van die sewentiende eeu - die tyd van die opkoms van die historiese denke en die aanwending van die histories-kritiese metode. Eeue lank was die teologie as geheel as één vakgebied beskou. Natuurlik het hierdie ontwikkeling die teologie in meer as een opsig ten goede gekom. Spesialisasie het moontlik geword en dit het tot verdieping van vakkennis gelei. Dit het egter ook meegebring dat die verskillende vakke so ver uitmekaar gegroei het dat die eenheid van die teologie as geheel daardeur geskend is. Is die verskillende teologiese vakke in werklikheid slegs verskillende gesigshoeke van waaruit dieselfde teologiese stof bestudeer word, of verwerk elke teologiese vak die teologiese stof op so 'n manier dat dit nouliks nog as dieselfde stof beskou kan word wat ook in die ander vakke bestudeer word? Produseer elke teologiese vak nie só sy eie perspektief op die teologiese stof, dat dit moeilik tot 'n eenheid saamgesnoer kan word nie? Afgesien van die teologieë van die Ou Testament en die Nuwe Testament, kry ons ook nog die teologie van Jeremia en Jesaja, en die teologie van Johannes, Paulus en Petrus. Selfs al sou die teoloogspesialis die boodskap van sy teks, perikoop, boek, skrywer, selfs van sy testament, met grammatikale ondersoek en die bepaling van die herkoms en betekenis van woorde, met die hulp van argeologiese fondse, vasgestel het. bly die vraag nog steeds: is dit ook die boodskap van die hele Bybel? Is die gevaar nie dat ons die diepste betekenis van die dele wat ons gebruik, verloor wanneer dit uit die totale verband uitgeneem en van die res geïsoleer word nie?

Geld hierdie bedenkinge moontlik net van die sogenaamde analitiese 
vakke terwyl die dogmatiek, waar daar sinteties gewerk word, en dus beskou kan word as integrasieoord van alle gegewens, bo hierdie tekortkominge verhewe is? Helaas, ook hier het die spesialisasie-obsessie sy tol geëis. Tradisioneel is die stof in agt-en-twintig onderafdelings (loci) met 'n aantal hoofafdelings verdeel: God (teologie), mens (antropologie), Christus (Christologie), Heilige Gees (Pneumatologie), verlossing (soteriologie), kerk (ekklesiologie) en die laaste dinge (eskatologie).

Ook met hierdie metode is die geleentheid vir spesialisasie geopen, maar ook hier het versnippering ingetree. Verskillende teoloë het in die verlede al hul hand gewaag aan monografieë waarin gepoog is om selfs die hele veld van die dogmatiek te dek. En steeds het die brandende vraag gebly: wat is die basiese kerntema van sy dogmatiek of binne watter raamwerk beoefen hy sy dogmatiek? 'n Indrukwekkende aantal monografieë is by geleentheid al genoem: 'n ongesistematiseerde sistematiese teologie, toe daar nie 'n antwoord gegee kon word op die vraag: wat bind hulle ten diepste saam nie?

'n Besondere vorm van fragment tree ook in die prediking na vore, naamlik wanneer die kerk as die belangrikste of selfs as die enigste terrein gesien word waar God gedien kan word. Dan word kerklike meelewing, en met name gemeentelike betrokkenheid, die barometer van Christelike lewe. Wie nie aan die plaaslike gemeentelike aktiwiteite meedoen nie, word erg verkwalik en word nie beskou as 'n meelewende Christen nie. 'n Positiewe, aktiewe Christelike lewe in die samelewing, waar gestry word om die handhawing en die deurwerking van Christelike beginsels word nie waardeer as 'n meewerking aan en 'n uitbreiding van die saak van God op aarde nie. In elk geval staan dit nie op dieselfde hoë vlak as meelewing aan die gemeentelike aktiwiteite nie.

Ten slotte is dit ook 'n ernstige vraag of die fragment van die Bybelse boodskap én van ons teologiese nadenke daaroor nie ook 'n belangrike bydrae gelewer het tot die fragment van die Christendom in die totstandkoming van die groot verskeidenheid kerke nie.

Die behoefte aan 'n sentrale tema in Gods openbaring in die Skrif en in die teologie, spreek myns insiens duidelik uit die sogenaamde genitief-teologieë: teologie van die bevryding (G Gutiérrez), teologie van die revolusie (R Shaull, en andere) teologie van die hoop (J Moltmann), teologie van die kultuur (Paul Tillich), ensovoorts. Hierdie metode lei nie tot 'n bevredigende oplossing nie, maar gee aanleiding tot verdere versplintering. Meer nog: dit tas ook die Bybelse kwaliteit van die teologie aan. Eerder as om die teologie van "binne uit", dit wil sê vanuit die Bybelse boodskap self te probeer verstaan, word die teologie van "buite af", dit wil sê, vanuit 'n bepaalde kultuursituasie geïnterpreteer en daarom ook vir 'n bepaalde politieke doel, gemanipuleer.

'n Tweede interessante poging uit die jongste verlede tot oplossing van die 
probleem vind ons by Gordon J Spykman ${ }^{3}$. Hy gaan van die oortuiging uit dat 'n algemene Bybelse lewens- en wêreldbeskouing aan die teologie en met name aan die dogmatiek as 'n prolegomena vooraf moet gaan. Dit word in samewerking met die Christelike filosofie opgestel. Self kies hy vir die Wysbegeerte van die Wetsidee. Of dit 'n oplossing kan bied is eweneens te betwyfel. Afgesien van die problematiese alreeds in die keuse van 'n Christelike filosofie (daar is ook ander Christelike filosofieë) is dit 'n vraag of selfs die Christelike filosofie só 'n rol, selfs nog vóór die dogmatiek begin het, mag speel.

Moet die teologie in die algemeen en die dogmatiek in besonder, nie eerder gelei, gestuur en beheer word deur wat as sentrale kerntema uit die Skrif self opkom nie? Moet ons nie soek na, en is daar nie 'n dringende behoefte aan 'n nuwe paradigma vir die beoefening van die teologie nie?

Vir 'n beantwoording van hierdie vrae kyk ons vir 'n kort oomblik na die aard van die Skrif self. Die Bybel is 'n verhaal oor God en sy omgang met die wêreld: sy skepping en onderhouding daarvan en sy bedoeling daarmee. Soms is daar selfs nog 'n dieper laag in die Bybel. Dan is die Bybel nie net 'n verhaal oor 'n bepaalde gebeure nie, maar die verhaal van 'n verhaal oor 'n gebeure wat êrens plaasgevind het, of nog gaan plaasvind. Maar hoeveel dieptelae daar in die Bybel ook al onderskei kan word en watter prosesse dit ook al deurloop het om by die oorspronklike skrywers uit te kom en die omweë van afskrywery wat gevolg is om uiteindelik die teks vir die huidige leser te word, én ding staan vas: die verhaal waarom dit gaan is die verhaal oor God en sy handelinge met die wêreld. Ten spyte van uiteenlopende literatuur-soorte soos prosa en poësie, vertellinge en wetsbepalinge, afstammingslyste en natuurbeskrywinge, historiese verhale en profesieë, verskillende soorte sages, mites, fabels, legendes en anekdotes opgeteken oor 'n periode van ongeveer 1500 jaar in verskillende kultuursituasies op verskillende plekke, verpak in 66 boeke verdeel in twee testamente, vorm, ten spyte van al die verskille, één verhaal die kern waaromheen alles draai.

Dit gaan in die Bybel dus nie om verskillende uiteenlopende en mekaar weersprekende of van mekaar losstaande verhale nie. Nee. Die één verhaal word telkens vanuit verskillende gesigspunte of perspektiewe belig. Die narratiewe teks van die Bybel ontplooi weliswaar'n pluraliteit van konsepte en 'n verskeidenheid konseptuele komponente, maar basies bly dit dieselfde verhaal wat in sy rykdom oopgedek word.

lets van dié rykdom het Calvyn raakgesien toe hy in sy voorwoord tot die Geneefse Bybel aan ons 'n ontroerende lofsang op die Bybel nagelaat het. Hy loof die Bybel as 'n boek van onskatbare waarde en onberekenbare hoë egtheid. "Dit is die sleutel wat vir ons die koninkryk van God open... Dit is die spieël waarin ons die aangesig van God aanskou... Dit is die koninklike septer waardeur Hy ons as sy volk regeer... Dit is die dokument van sy verbond... Dit is die enigste voedsel vir ons siel". 
Beide die verhaal en die gebeure waaroor die verhaal dit het, naamlik God se handelinge met sy wêreld, het 'n historiese ontwikkeling deurloop. Trouens, God gaan nog steeds met sy handelinge voort. By die skepping het God nie alles met die wêreld gedoen wat Hy daarmee kón doen en daarmee wó́ doen nie. Ons weet daarom aan die einde van die Ou Testament méér van God se omgang met sy wêreld as wat ons daarvan hoor in die eerste boek van die Ou Testament, en weet ons aan die einde van die Nuwe Testament ook veel meer as aan die begin en die einde van die Ou Testament. Die feit dat God die skepping goed en selfs baie goed genoem het na Hy dit voltooi het, beteken vir geen oomblik 'n afgeronde en voltooide skepping met die afwesigheid van gebeurtenisse en prosesse waarin die skepping nie tot groter volheid en groter heerlikheid kon kom nie. Die begin van die skepping (proton) is eenvoudig nie gelyk aan die voleinding (eskaton) van die skepping nie.

Dat die skepping beweeg van die proton na die eskaton is nie te danke aan die kragte inherent aan 'n histories-dinamiese proses eie aan die skepping self nie, maar is die resultaat van Gods onafgebroke aktiewe en onmisbare bemoeienis met sy skepping. As geheel, maar ook in elke onderdeel, as stof, plant, dier, mens en engel, is die skepping vir sy ontstaan en voortbestaan, vir sy sin en waarde, volledig van die Skepper afhanklik. Uit homself kon die skepping nie voortgekom het nie, en uit homself kon hy nie sy God-bepaalde bestemming bereik het nie. Die verhaal van die skepping waarvan die potensialiteite gerealiseer word onder die voorsienige leiding van God ook wanneer dit bewustelik Hom nie wil gehoorsaam nie, maar 'n eie selfstandige weg wil gaan, dié verhaal vertel die Bybel ons in 'n uiteenlopende verskeidenheid van historiese taferele en baie dikwels ook waarlik aangrypende en verstommende momente.

Wel is die lewende God van die Bybel drie wat sy persone betref, maar na sy wese is Hy nie 'n verskeidenheid gode nie, maar één God. Hierdie één God het één skepping uit die nie-syn tot die syn geroep, met één bestemming vir die ganse skepping, en daarom word ook die eenheid van die inhoud van Gods openbaring dáárin uitgedruk dat die Woord na die skepping kom met één opdrag: dien God!

Bybels gesien, is die skepping ten diepste dan ook niks anders nie as 'n simfonie waar die groot verskeidenheid skepsels elkeen in ooreenstemming met sy eie unieke aard, die lof van die Skepper besing.

Wanneer die mens vanweë sy ongehoorsaamheid aan God in sonde val, en dit verreikende gevolge het ook vir die skepping, kondig God nie verskillende nie, maar één verlossingsplan aan waardeur die skepping en die mens weer herstel sou word. Hierdie verlossing is bewerkstellig deur niemand anders nie as die Seun van God wat mens geword het en aan die kruis van Golgota gesterf het. En ofskoon hierdie verhaal in besonderhede in die Nuwe Testament vertel word, impliseer dit nie dat die Ou Testament niks daarmee te doen het nie, en dat verlossing en heil 
eksklusief 'n Nuwe- Testamentiese aangeleentheid is nie. By geleentheid het Luther selfs gesê: "Die Bybel is die krip waarin Jesus lê". Daarmee word natuurlik nie bedoel dat vanaf elke teks, elke hoofstuk en elke boek van die Ou Testament 'n direkte lyn na Jesus Christus getrek kan word nie. Dit sou selfs te ver gaan om, in terme van Luther se beeld, te sê dat die Ou Testament die materiaal voorsien waarvan die krip vir die Nuwe Testamentiese Jesus gemaak is.

Teen elke vorm of graad van devaluering van die eiesoortigheid van die Ou Testament moet inderdaad gewaarsku word, maar ewemin mag die wesenlike eenheid en diepe samehang in wat God aan ons oor skepping en herskepping wou openbaar, misken word.

Die verhaal wat die Bybel ons vertel, gaan nie maar net oor die objektiewe feite van God se handelinge met die wêreld en sy bedoeling daarmee nie, dit gaan ook oor wat God van die mens verwag ten opsigte van sy handelinge. Beter gestel: dit gaan ook om 'n openbaring van die mens se eie posisie in en sy reaksie op die gebeure van God se handelinge. Die normatiewe karakter van die Bybel maak van die leser of die hoorder iemand wat homself midde in die aksie vind waarvan vertel word. Meer nog: die leser of hoorder is nie maar net 'n waarnemer van die gebeure waaroor die verhaal dit het nie. Hy is self betrokke by die gebeure. Die verhaal gaan nie maar net oor ander mense nie, die verhaal gaan ook oor homself.

Die Bybel is die lewende Woord van God, geïnspireer deur die Heilige Gees, en daarom die verhaal van en bedoel vir alle mense onder alle omstandighede en in alle tye. Daarmee is gesê: die Bybel is nie net informatief nie, maar ook normatief en imperatief. Dit sê nie net wat mense se plek is in die verhaal oor God se handelinge nie. Dit sê ook hoe hulle moet dink en wat hulle moet doen in die konkrete omstandighede van hulle eie lewe - eweneens onder die leiding van die Heilige Gees.

Die Bybel is dus wel 'n verhaal, maar nie net 'n verhaal sonder meer, waarmee die leser kan doen wat hy wil nie. Hy kan dit nie ignoreer of tot fiksie degradeer nie. Die Bybel is 'n verhaal-met-dogma en 'n verhaal-met-moraal. Dié stelling moet nie misverstaan word nie. Die begrip dogma dui op die resultaat van besinning oor die openbaring wat gesagvol geformuleer word, en wat dan as belydenis, dit wil sê as inhoud van geloof aangebied word. Só verstaan, kan ons sekerlik nie sê dat die verhaal wat die Bybel vertel 'n aaneenskakeling is van geformuleerde leerstellige waarhede nie. Wat ons wél kan sê is dat die Bybel ons materiaal bied wat deur besinning tot dogma omskep kan word. Die begrip moraal weer, het oorspronklik te doen met gewoonte en selfs met inbors. Dit dui dan aan dat daar in die lewe van 'n mens 'n sekere reëlmaat voorkom sodat van 'n duidelike lewenspatroon gepraat kan word. Dit het te doen met'n bepaalde kontinuïteit in of duurte van gedraginge sodat daar van 'n vaste gewoonte of van 'n herkenbare en van 'n ander onderskeibare lewenstyl sprake is. Só verstaan, gee die verhaal van die Bybel 
inderdaad moraal, want die lewe van gelowiges van daardie tyd en die norme waarvolgens hulle hul lewe ingerig het, word aan ons meegedeel. Die probleem is net dat daar so 'n enorme afstand is tussen die omstandighede wat die moraal van die Christene in Bybelse tye beïnvloed het, en die omstandighede waaronder die twintigste-eeuse Christen leef en waarin hy sy lewe moet stileer. Ons sal die verhaal oor Christene se moraal in Bybelse tye dus moet vertaal in die wete dat sekere sake deur die eeue heen dieselfde bly, maar dat daar sekere sake is wat beslis verander. Die kern sal van die wisselende onderskei moet word.

Die verhaal wat die Bybel ons vertel oor God se omgang met sy wêreld, roep ons tot geloof en tot handelinge, tot leer en lewe. Die verhaal wat ons lees en waarvan ons ontdek ons self deel uitmaak, gaan juis om die vulling van dié geloof en om die gestaltegewing van die handelinge. Beide vulling en gestaltegewing is eweneens ' $n$ historiese proses soos trouens die verhaal self ' $n$ historiese verloop deurgemaak het. Die Bybel vertoon 'n hegte eenheid wat by geleentheid al 'n heilige eenheid genoem is. Die rede vir hierdie merkwaardige verskynsel, waarin tegelyk die uniekheid van die Bybel ten opsigte van alle ander geskrifte in die wêreld bestaan, is ten diepste geleë in die feit dat daar, bo of agter al die menslike skrywers, net één Goddelike Skrywer was, naamlik die Heilige Gees.

Trouens, dit was die Heilige Gees wat die Bybelskrywers, bestem vir die heerlike taak om eenmaal mee te werk aan die opskrifstelling van Gods Woord, reeds van hulle jeug af daarvoor voorberei het, met aanleg en talente toegerus en so die ganse persoonlikheid van die Bybelskrywers tot selfbewuste en selfwerksame organe van sy inspirasie gemaak het. Dit was Hy, die Gees van God, wat in die harte van die Bybelskrywers ingegaan en hulle só geïnspireer en in beweging gebring het, dat hulle self begin soek, dink, spreek en skrywe het. En wat hulle uiteindelik, ná besinning en navorsing, ná worsteling en gebed as hulle antwoord op die woord en leiding van die Heilige Gees neergepen het, was aan hulle deur die Gees gegee. Ons het nie in die Bybel die neerslag van die Bybelskrywers se eie individuele geloofservaring of geloofsuitdrukking nie, ook nie die resultaat van hul eie min of meer selfstandige en van Hom onafhanklike geloofsinsig nie, maar'n getuienis wat van die Heilige Gees self afkomstig is en wat Hy aan hulle ontlok het, en wat met betrekking tot bepaalde sake moontlik selfs hul eie begrip en insig te bowe kon gegaan het.

Die bedoeling van God met sy skepping, is gereflekteer in die bedoeling van die Heilige Gees met die Bybel. Daarom is die eenheid van die Bybel nie net geleë in die feit van die één Skrywer nie, maar met name ook in die één sentrale boodskap wat Hy aan al die Bybelskrywers meegedeel het, en die kerninhoud uitmaak van wat hulle weer aan ons meedeel.

Die Bybel vertel ons nie van gebeurtenisse in 'n ander wêreld op 'n ander planeet nie. Dic Bybel laat ons kyk na ons self en die dinge om ons. Hy leer ons 
ook om te kyk na die agtergrond van alle dinge. Hy voer ons na die anderkant van die empiries waarneembare, na wat ons met die oog nie kan sien nie, met die oor nie kan hoor nie en met hande nie kan vat nie - en dit wil hy hê moet ons in die geloof aanvaar. Die Bybel is by uitstek 'n boek van metafisika. 'n Boek van die anderkant van die fisiese. 'n Boek nie sonder die fisiese nie, maar aan die anderkant van die fisiese. Beter gestel: die fisiese in sy ware legitieme konteks; die fisiese plus die nie-fisiese. Agter die kosmos wil die Bybel die oorsprong van die kosmos laat sien: die lewende, enige en ewige God, die sprekende, skeppende en onderhoudende God. Agter en bo die geskiedenis wil die Bybel die Een laat sien wat in en deur die geskiedenis worstel om die herstel van sy verworpe heerskappy. In die ganse kosmiese gebeure en chaos van die volkeregeskiedenis is God aan die werk om dwarsdeur en teen die weerbarstigheid van mens en wêreld in, die gevalle kosmos vas te hou en terug te bring na sy oorspronklike bestemming en só die nuwe hemel en die nuwe aarde ' $n$ werklikheid te maak.

Sy greep na 'n verloregaande wêreld kry 'n verbysterende konkreetheid as die soekende God self uit die hemel neerdaal in die geskiedenis om persoonlik op aarde aan die mens die diepte en omvang van sy heilige liefde te kom betuig.

Die Bybel vertel ons nie net van die agtergrond van alie dinge nie, maar ook van die dieptegrond van alle dinge, en met name van wat daar in die hart van die mens aangaan. Dit gaan met ander woorde nie net om die handelende God nie, dit gaan ook om die handelende mens. Die mens geskep as beeld van God, wat aanvanklik God in alles gehoorsaam was, word die eiewillige, beter-as-God-wetende mens, die rebellerende mens wat in opstand kom, nie net teen God nie, maar ook teen sy naaste. Reeds op die eerste bladsye van die Bybel lees ons die tragiese verhaal van 'n man wat meen dat probleme opgelos kan word deur die neem van die lewe van 'n ander mens - selfs al is hy sy eie broer. So brei die sonde uit om uiteindelik alle verhoudinge waarin die mens lewe, fundamenteel aan te tas.

Maar dan word vir ons ook geteken die mens wat Gods appellerende Woord hoor en as begenadigde terugkeer na die gemeenskap met God en sy heerskappy oor sy lewe aanvaar.

Die mens wat die boodskap van die Bybel gehoor en verstaan het, en die heerskappy van God in sy lewe aanvaar en hom onvoorwaardelik daaraan onderwerp het, kan nie anders as om ook radikaal en totaal in terme daarvan te dink en daaruit te gaan lewe nie. Dit word die perspektief van waaruit hy na die lewe en die wêreld gaan kyk. So ontwikkel hy dan 'n lewens- en wêreldbeskouing as 'n konseptuele raamwerk waarbinne hy die basiese waarhede van die Skrif-boodskap tot 'n eenheid saamvat. Vir die Bybèlgelowige is daar dus nie so iets soos neutraliteit nie, dit wil sê 'n plek, 'n situasie of verhoudinge waar God nie heers nie, waar die beginsels van sy Woord nie geld nie, en waar die mens Hom nie kán en nie ook móét gehoorsaam nie. 
Gevolglik is daar vir die Bybelgelowige ook nie iets soos dualiteit nie, dit wil sê 'n terrein waar hy God dien en 'n terrein of terreine waar hy hom slegs laat lei deur die redelikheid van sy verstand en die wetmatigheid van die saak waarmee hy besig is nie? Daar bestaan trouens net één terrein en dit is die wêreld, en daar het ons net één roeping en dit is om God gehoorsaam te wees. Vir hierdie één terrein het God sy wette op twee maniere gegee: van "buite af" in sy geskrewe Woord en van "binne uit" in die kosmos self. Alles wat ons tot hiertoe gesê het, kan beskou word as behorende tot die van "buite af" perspektief van Gods wil. Wat nou die laasgenoemde betref: Die wette wat God self as Skepper en Onderhouer in die kreatuurlike werklikheid gelê het, moet die mens in sy kultuuraktiwiteite ontdek, formuleer en gehoorsaam. So is daar fisiese wette, biologiese wette, denkwette, logiese wette, sosiale wette, estetiese wette, sedewette, godsdienstige wette - alles konkrete uitdrukking van God se wil vir hierdie wêreld waarin ons leef. Afgesien hiervan is daar ook samelewingsverbande soos byvoorbeeld die huwelik, gesin, kultuur, staat en kerk - 'n groot verskeidenheid sake wat nie tot mekaar herlei mag word of in terme van mekaar verklaar mag word nie. Elkeen is nie net soewerein binne sy eie bevoegdheid nie, maar is ook met mekaar saam verbind tot 'n organiese geheel. Belangrikste van alles is egter: elkeen verteenwoordig 'n terrein waar God en Hy alleen gedien moet word, en almal saam is die mens se konkrete diens aan God. Die Bybel noem dit die mens se godsdiens.

Wat ons tot hiertoe probeer sê het, is dat die Bybel die verhaal is van één boodskap: God se handelinge met die wêreld, waaruit daar één oproep tot die mens kom: dien God in alles.

Om 'n beeld te gebruik: soos bloed deur die ganse menslike liggaam vloei en in alle liggaamsorgane soos die hart, longe, hande, bene, oë en ore 'n lewensbelangrike funksie vervul, en genoemde organe nie net tot lewe opwek nie, maar ook tot 'n eenheid saambind, so vloei daar ook deur die verhaal van die Bybel, één sentrale boodskap wat alle onderdele saambind en die verskeidenheid in 'n eenheid saamtrek.

Nog 'n beeld: soos die argitek 'n argiteksplan opstel waaraan die bouer hom nougeset moet hou by die oprigting van die gebou, so het die Skepper ook 'n grondplan vir sy skepping. Omdat die Bybel die skriftelike verhaal is oor hierdie skeppingshandeling van God, sal ook die Bybel 'n weerspieëling wees van die grondplan. Só verstaan, volg die plan nie op die skepping nie, maar gaan daaraan vooraf. Eweneens lê die plan ten grondslag aan die ontwerp van die Bybel en is nie die resultaat daarvan nie. Soos die Bouer-god dus voortgaan met sy bouwerk word sy plan al duideliker, ook vir hulle met wie daar gebou word. Die verhaal oor dié gebeure moet ook so verstaan word.

Hierdie geïntegreerde Skrifbeskouing sal ook 'n geïntegreerde teologie as resultaat hê. Dit sluit nie uit dat die teologie nog steeds in 'n verskeidenheid 
dissiplines onderverdeel word en só die geleentheid bied vir die so nodige spesialisasie nie, maar dan word in die verskeidenheid steeds éen sentrale boodskap gehoor. In die teologiese literatuur word verskillende suggesties aangetref met betrekking tot die formulering van die sentrale tema in die Skrif: bekering, oorwinning oor sonde, wet en evangelie, belofte en vervulling, verbond, Jesus Christus, ensovoorts. Na my oordeel is daar geen beter begrip wat as samevatting en uitdrukking van die Skrifinhoud diens kan doen, as dié van die koninkryk van God nie. Kyk ons na die struktuur van die openbaring aangaande die koninkryk, soos die Skrif dit bied, kan die volgende basiese komponente onderskei word:

-die Koning is God drie-enig

-die Koning heers deur sprekend te skep en te onderhou

-die Koning skep en heers or sy onderdane: stof, plant, dier, mens en engele -die Koning se onderdane gehoorsaam Hom

-die Koning se onderdane leef elkeen individueel en gemeenskaplik in gehoorsaamheid aan sy wil en word deur Hom geseën.

In die lig hiervan kan die koninkryk soos volg omskrywe word: die koninkryk van God is sy heerskappy oor en die gehoorsame aanvaarding daarvan deur sy onderdane: stof, plant, dier, mens en engele. Of anders: die koninkryk van God breek deur daar waar sy onderdane aan hul Godgegewe bestemming beantwoord. Nog korter: die koninkryk is die triomf van Gods wil. Natuurlik word die begrip Koninkryk nie oral met al sy komponente in die Skrif gebruik nie. Die boeiende is egter dat daar nie 'n enkele boek in die Bybel is waar die saak van die koninkryk of bepaalde komponente daarvan nie aanwesig is nie. Daarom kan met vrymoedigheid beweer word dat dit in die ganse openbaringsgeskiedenis van die Ou en die Nuwe Testament gaan om die koninkryk van God.

In die openbaringsgeskiedenis van die Ou Testament gaan dit om die oorsprong van die koninkryk in die tyd (die skepping); om die etiese grondreëls van die koninkryk (die wet); om die voorlopige partikularistiese gestaltegewing aan die koninkryk in Israel (die profete); om verskillende aspekte van die koninkryk (die geskrifte). In die openbaringsgeskiedenis van die Nuwe Testament gaan dit om die herstel van die koninkryk in Jesus Christus (evangelies); om die universele verbreding van die koninkryk (Handelinge); om die intensiewe ontvouing van die koninkryk (Briewe) en om die finale voleinding van die koninkryk (Openbaring). Hiermee word nie 'n program voorgestel vir 'n nuwe soort genitief-teologie nie: 'n teologie van die koninkryk. Hiermee word voorgestel dat die ganse teologie verstaan sal word, bestudeer sal word en natuurlik ook verkondig sal word as koninkryksteologie. Dit is waarom dit in die Skrif gaan: die koninkryk van God. Natuurlik gee die Bybel nie 'n sistematiese en logiese uiteensetting van die begrip 
koninkryk nie - soos trouens ook van geen ander begrip nie - maar die verhaal van die Bybel vertel die ontvouing van hierdie dinamiese werklikheid wat koninkryk genoem word, ons toetrede daartoe, ons plek en taak in die opbou van die koninkryk en uiters belangrik, ons word ook meegedeel hoe ons die verhaal van die koninkryk verder moet vertel.

In die begrip koninkryk, verstaan soos die Bybel ons dit laat verstaan, kry ons die integrasiebeginsel waar alle brokstukke waarhede tot 'n oorsigtelike geheel saamgesnoer word, en in 'n sinvolle boodskap uitmond. Hier vind ons die onderlinge samehang en intieme afhanklikheid van die verskeidenheid, soms selfs vreemde gebeurtenisse waarvan die Bybel ons vertel.

Helaas moet ons ook sê dat aan die begrip koninkryk nie altyd selfs in die gereformeerde teologie die plek toegeken is, en toegeken word, wat hy wel verdien nie. Ons kan ook nie sê dat dit 'n sentrale plek in die struktuur van ons konfessies inneem nie. Trouens, daar word dit volledig onderbelig.

Waar wél gewerk word met en aandag gegee word aan die koninkryk word dit nie altyd in sy breë, fundamenteel-omvattende Bybelse betekenis gedoen nie. Dit word dikwels eskatologies verskuiwe na die toekoms, antropologies vereng tot die mens, soteriologies verskraal tot die heil van die mens, vertikalisties beperk tot die mens se verhouding met God, psigologies tot die innerlike van die mens gereduseer, eties tot die lewe van die mens alleen herlei, individualisties tot die enkeling begrens, of ekklesiologies vereenselwig met die kerk.

Eén ding is vir ons duidelik: vir die Bybel en dus vir die teologie, vir die kerk, vir die praktiese Christelike lewe en vir die teoretiese Christelike lewens- en wêreldbeskouing, ja, vir die ganse aardse bestaan van alle mense, is die koninkryk van God van fundamentele lewensbelang. Dit is die koninkryk wat ons denke normeer en daaraan inhoud en perspektief gee; dit is die koninkryk wat ons lewe modelleer en dit voorsien van vorm en styl. Dit is die koninkryk wat ons onder die hoogste norme stel vir ons denke en emosie, instelling en gesindheid, gedagte, woorde en werke, drome en ideale. As dinamies ontwikkelende, normatiewe werklikheid, is dit die koninkryk wat ons leer om die verlede nie gering te ag nie, die hede nie oor te aksentueer of te onderwaardeer nie, en die hoop vir en die uitsig op die toekoms nie te laat verdof nie. Dit is die koninkryk wat in die harte van sy burgers die wete steeds lewend hou dat hulle (nog) nie gearriveer het nie - nie in hulle huwelike nie, nie in hulle arbeid en besittings nie, nie in hulle prestasie nie maar dat hulle bewustelik en blymoedig op weg is na 'n beter, finale vaderland. Op weg daarheen weet hulle dat niks so belangrik is as die koninkryk nie, maar juis daarom is alles so belangrik: huwelik, arbeid, besittings en prestasie, want juis dáar moet tekens van die koninkryk opgerig word in die aktuele en daadwerklike gehoorsaamheid aan God. 
1 Afskeidsrede gelewer op 28 Oktober 1993 aan die Universiteit van Pretoria.

2 U sal egter wel begrip daarvoor hê wanneer ek aan die einde van 'n sewe en twintig jare lange akademiese loopbaan - vyf jaar daarvan aan die Universiteit van Stellenbosch (1966-1970) en twee en twintig jaar aan die Universiteit van Pretoria (1971-1993) - met een enkele woord almal wat dit vir my op verskillende maniere, deur my die geleentheid te gee, die ruimte te skep of my te inspireer om dié werk te kon gedoen het, van harte te bedank. Oor die algemeen: die skole wat ek besoek het, die universiteite waar ek studeer het, onderwysers en dosente wat 'n blywende stempel op my afgedruk het, die Ned Geref Kerk en die universiteite waar ek doseer het, my kollegas, die studente en ons sekretaresses. In besonder wil ek graag, wat die departement dogmatiek betref, my kollega prof Conrad Wethmar noem. Sy begrip vir veeleisende verpligtinge soms buite die direkte departementele begrensing, sy bereidheid tot hulp, die deeglikheid waarmee hy alles wat hy doen aanpak, sy fyn aanvoeling vir die sensitiewe in medemenslike verhoudinge, dit alles het van hom 'n kollega sonder weerga gemaak. Met groot dankbaarheid roep ek ook in herinnering die onmisbare rol wat my vrou vervul het en die vreugde wat my kinders en later kleinkinders my verskaf het. Uiteraard dink ek met diepe piëteit ook terug aan my ouers. Wat hulle vir my en my twee susters - wat gelukkig ook hier teenwoordig mag wees - beteken het, kan nooit in woorde uitgedruk word nie.

Ek vra ook u geduld vir 'n enkele opmerking oor die verhouding van dosent en student. Die onderrig van teologie is vir my 'n vennootskaplike onderneming tussen 'n ouer teoloog en 'n jonger teoloog. Die bydrae van die ouer teoloog mag inhoudelik egter nie neerkom op die oordrag van sy eie geestelike outobiografie nie, want dan hou hy sy studente op 'n niveau en dit sou 'n onreg teenoor die studente impliseer. Die dosent moet probeer vergesigte open wat hyself nie het nie, sy studente hoogtes laat bereik wat hy self nie behaal het, en desnoods weet dat hy dit nooit sal haal nie, hy moet probeer weë oopdink tot waarhede wat hy self nie kon verower nie. En die bydrae van die student? Deur toegewyde arbeid, indringende vrae, sy dors na kennis soos dit blyk uit die lyftaal van 'n entoesiastiese houding en die merkbare vonkel in die oog, moet die student die dosent inspireer om dosent te wees. Ek het alle rede om ook my studente te bedank vir hulle bydrae deur die jare.

Die roeping tot dié soort werk kom natuurlik van ons hemelse Vader wat nietige en brose mense met beperkte moontlikhede in sy diens gebruik. Dat Hy juis my raakgesien en in ryke mate aan goeie gesondheid laat deel het, is enkel aan sy uitverkiesende genade te danke. Dames en Here, u teenwoordigheid hier as teken van u belangstelling en meelewing, vervul my met diepe dankbaarheid. Wees verseker van my opregte waardering.

3 Reformational Theology. A new paradigm for doing dogmatics, Eerdmans, Grand Rapids 1992. 